\title{
Acute Perinatal Infection and the Evidenced-Based Risk of Intrauterine Diagnostic Testing: A Structured Review
}

\author{
R. Douglas Wilson \\ Department of Obstetrics and Gynecology, Cumming School of Medicine, University of Calgary/Alberta Health \\ Services, Calgary, AB, Canada
}

\section{Keywords}

Perinatal infection - Vertical transmission - Fetal infection . Maternal infection - Diagnostic testing · Intrauterine testing · Procedure-related perinatal loss rate

\begin{abstract}
Background: The prevalence of perinatal infection from maternal exposure is increasing. The prevalence of acute maternal infections identifies cytomegalovirus, parvovirus B19, toxoplasmosis, and varicella as the most common organisms and in the order of frequency. Maternal informed consent and understanding is required before intrauterine testing for fetal infectious and possible genetic risk assessment. Methods: This structured review of the reproductive published literature focuses on the risks of amniocentesis and cordocentesis diagnostic procedure-related fetal loss rates and fetal vertical transmission (VT) rates from published infected pregnant cohorts. Results: The total postprocedure fetal loss rate for diagnostic amniocentesis procedures, in limited infectious cohorts, is $1.5 \%$ and does not appear to be increased compared to "noninfected" amniocentesis cohorts using an estimated background spontaneous fetal loss rate (no procedure) of $0.65 \%$. The "pooled" unintended fetal loss rate is from small infected population cohorts, but can be used for counseling purposes. Postcordocentesis fetal loss risk, in an
\end{abstract}

infected cohort, is not possible to estimate due to limited data. The "biological spontaneous fetal loss rate" risk with a perinatal infection (positive or negative fetal anomalies) and no diagnostic procedure before 20 weeks of gestation is reviewed. The risk of $\mathrm{VT}$ in acute infection cohorts as a result of the intra-amniotic diagnostic procedure is not found to be increased. Conclusion: The unintended "fetal loss" rate after amniocentesis for perinatal infected cohorts is similar to that of noninfected cohorts, but the estimate is based on limited infected cohorts. There was no procedure-based risk of fetal VT in the infected cohorts, but identification of postprocedure maternal bleeding into the amniotic cavity increases the potential risk. Maternal knowledge translation and an informed consent process with risk-benefit maternal/fetal risk counseling are required prior to any diagnostic amniocentesis procedure.

(c) 2020 S. Karger AG, Basel

\section{Introduction}

The prevalence of maternal-fetal risk with primary exposure to a potential teratogenic viral or nonviral organism is likely to increase due to maternal exposures to infectious scenarios. Infectious exposure during pregnancy has become more frequent and complex due to immigra-

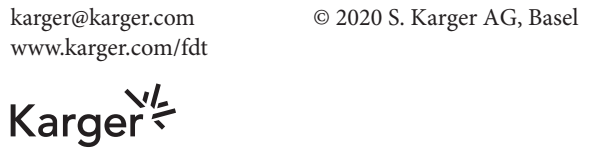


tion, international travel destinations (ZIKA virus, hepatitis, COVID-19), increased viral morbidity (H1N1, Ebola), and decreasing population utilization of primary vaccination and annual influenza vaccination for the protection of families/children (rubella, varicella, pertussis) [1-6].

Congenital viral infections in England have appeared to increase over the last five decades, but this finding may be due to more sensitive diagnostic techniques and postnatal retrospective screening programs such as neonatal hearing screening [7].

An accurate maternal-fetal infectious exposure diagnosis is required for an informed counseling and consent decision process. A maternal perinatal infectious exposure scenario leads to the question "Will this infection affect my baby and how serious will it be?"

There are limited infection-exposed cohorts with diagnostic testing available for evaluation, while a recently published opinion indicates that "guideline summation with recommendation should be initiated even if the evidence is considered insufficient" [8]. This structured review for a fetal infectious morbidity/mortality assessment will consider the indications for a diagnostic procedure, gestational age procedure timing, and diagnostic procedure risk after a suspected acute maternal infectious exposure, and summarizes the available evidenced-based knowledge to enhance maternal knowledge translation and informed consent.

\section{Methods}

This structured review of the reproductive published literature is focused on the risks of diagnostic procedure-related loss from published infected pregnant cohorts. Published literature was retrieved through searches of PubMed, National Society Guidelines (Society of Obstetricians and Gynecologists of Canada, American College of Obstetrics and Gynecology, Society of Maternal-Fetal Medicine, Royal College of Obstetrics and Gynecology, and United States Preventive Services Task Force), and the Cochrane Library using appropriate controlled vocabulary (amniocentesis, cordocentesis, procedure pregnancy loss risk, viral vertical transmission [VT], fetal and neonatal infection) and key words (maternal infection/exposure, varicella, cytomegalovirus [CMV], parvovirus $\mathrm{B} 19$, toxoplasmosis). The results were restricted to guidelines, systematic reviews, randomized controlled trials/controlled clinical trials (if available), and observational case control/case series studies from 2005 to 2020 published in English. Updated literature searches were completed on a regular basis through March 2020 and were incorporated into the structured review.

The structured review will consider a number of questions related to acute perinatal infections: (1) Which common pregnancyassociated viral/nonviral infections have diagnostic tested cohorts? (2) What is the diagnostic procedure-related fetal loss risk estimate for amniocentesis and cordocentesis in noninfected pregnancy cohorts? (3) What are the prenatal imaging features (ultrasound $[\mathrm{US}] /$ magnetic resonance imaging $[\mathrm{MRI}])$ that are associated with fetal infectious morbidity? (4) What are the maternal and fetal counseling and diagnostic testing indications in presumptive infected pregnancies (infection - maternal blood serology and possible viral load estimation; specific infected fetal and placental imaging patterns; directed amniotic fluid [viral DNA PCR]/fetal blood [viral DNA PCR/platelet count] testing; genetic [chromosomal microarray or karyotype] testing if indicated; optimal procedural gestational age consideration)? (5) What is the reported postprocedural fetal loss and/or fetal VT risk in the maternally infected pregnant cohorts (nonbacterial etiology)?

\section{Results}

\section{Question 1}

CMV, parvovirus B19, toxoplasmosis, and varicella are the most common acutely exposed perinatal infectious illnesses that require maternal assessment/diagnosis for possible maternal exposure/risk or if US fetal disruptive anomalies are identified, indicating the possibility of an unexpected fetal viral exposure as part of the differential diagnosis [1-6].

\section{Question 2}

Sequential systematic reviews (SRs) and meta-analyses (MAs), from 2015 to 2019, provided large data sources for procedure-related fetal loss assessments following intraamniotic diagnostic testing in noninfected diagnostically tested cohorts, generally for a fetal genetic evaluation [919]. The SRs/MAs $[9,10,17,18]$ identified the amniocentesis procedure-related fetal loss risk at $0.11-0.35 \%$ ( 1 loss per 290-300 to 900) with a reported control spontaneous fetal loss rate of $0.58-0.67 \%$ (no procedure; approximately 1 per $150-170$ pregnancies). Subsequent SRs/MAs by the same research group reported an added procedurerelated fetal loss risk of $0.11 \%$ (2015 SRs/MAs) followed with an increased added procedure-related fetal loss risk of $0.35 \%$ (2018 SRs/MAs) [10, 17]. An additional SR/MA (2019) reported the weighted procedure-related risk of miscarriage following amniocentesis as $0.30 \%$ (95\% CI 0.11-0.49) [9].

The prenatal diagnosis center-based amniocentesis cohorts [11-15] (with possible inclusion in the SR/MA publications) reported total postprocedure fetal loss rates estimated at $0.48-0.86 \%$ (approximately 1 per $90-200$ procedures); some cohorts reported the estimated control spontaneous fetal loss rates in screened pregnant (no procedure) populations to be $0.65-0.67 \%$ (approximately 1 per 150 pregnancies). 
Table 1. US and MRI findings associated with perinatal infection [6, 27-29]

\begin{tabular}{|c|c|c|c|c|}
\hline US abnormalities & CMV & $\begin{array}{l}\text { Parvovirus } \\
\text { B19 }\end{array}$ & Toxoplasma & Varicella \\
\hline \multicolumn{5}{|l|}{ Abdominal } \\
\hline Ascites & + & & + & \\
\hline Echogenic renal & + & & & \\
\hline Hepatomegaly & + & & + & \\
\hline \multicolumn{5}{|l|}{ Cardiac/thoracic } \\
\hline Pericardial effusion & + & + & + & \\
\hline Calcifications & & & & + \\
\hline Cardiomegaly & & + & & \\
\hline Pleural effusion & & + & + & \\
\hline \multicolumn{5}{|l|}{ Placental } \\
\hline Hydrops & + & + & + & + \\
\hline Edema & & + & & \\
\hline MCA with PSV & & + & & \\
\hline Polyhydramnios & & & & + \\
\hline Brain MRI & $\begin{array}{l}\text { cerebral calcification }(70 \%) \text {, } \\
\text { ventriculomegaly, white matter } \\
\text { disease, neuronal migration } \\
\text { disorders, microcephaly }\end{array}$ & & $\begin{array}{l}\text { hydrocephalus, intracranial } \\
\text { calcifications, parenchymal } \\
\text { destruction, volume loss }\end{array}$ & $\begin{array}{l}\text { variable (not well defined } \\
\text { and likely dependent on } \\
\text { gestational age at exposure) }\end{array}$ \\
\hline
\end{tabular}

CMV, cytomegalovirus; IUGR, intrauterine growth restriction; MCA, middle cerebral artery; MRI, magnetic resonance imaging; PSV, peak systolic velocity; US, ultrasound.

The "no procedure" spontaneous background rate of miscarriage after 14 gestational weeks is important for patient informed consent. The reported "no procedure" spontaneous fetal loss rates of $0.65-0.67 \%$ from the above single-center studies are very consistent with earlier reported "control cohorts" of $0.7 \%[20,21]$.

The use of cordocentesis in noninfected diagnostic cohorts reports a postprocedure fetal loss rate based on the fetal pathology at the time of the procedure. Kunochova et al. [22] report on 78 diagnostic and 14 therapeutic cordocentesis procedures with postprocedure fetal loss rates of $3 \%(2 / 78)$ and $14 \%(2 / 14)$, respectively. For the testing indication of fetal hydrops, 455 cordocentesis procedures were used in 208 pregnant women ( 74 women had $>1$ cordocentesis with a mean of 2.2 procedures and a maximum of 18) [23]. Indications for cordocentesis were isoimmunization (55.6\%), nonimmune fetal hydrops (17.5\%), chromosomal diagnosis $(22.2 \%)$, and other indications ( $4.8 \%$ ), with $51.2 \%$ associated with a blood transfusion. The overall fetal demise rate within 2 weeks of cordocentesis was $10.2 \%$ (3.2\% with no hydrops, 9.1\% with immune hydrops, $31.7 \%$ with nonimmune hydrops).

Cordocentesis for "at-risk" fetal anemia cohorts as the testing indication reported 223 procedures in 153 pregnancies, with fetal loss in 11 cases, but 7 losses were identified as disease-related (95\% CI 1.4-2.7; 4/223 [1.7\%]) [24]. A fetal hemoglobinopathy cohort (case-control) with 5,506 cordocentesis cases reported a fetal loss rate of 1.9 vs. $1.0 \%$ (RR 1.9, 95\% CI 1.4-2.7) [25].

\section{Question 3}

US (plus or minus MRI) imaging is the primary screening and diagnostic assessment for the identification of fetal "disruptive" structural anomalies following perinatal infectious exposure. Voekt et al. [26] reported on 392 patients (2008-2015) with US indications consistent for maternal STORCH exposure in pregnancy (syphilis, toxoplasmosis, rubella, CMV, herpes simplex, and others [HIV, hepatitis B and C, parvovirus B19, enterovirus, varicella, Leptospira interrogans]). The most common imag- 
Table 2. Perinatal infections - screening, investigation of a symptomatic maternal illness, imaging features, and infection/genetic risk for diagnostic testing $[1,28,30]$

\begin{tabular}{|c|c|c|c|c|}
\hline Infection & Prenatal screening & Investigations (maternal/fetal) & Imaging (see Table 1 for details) & Infection risks \\
\hline $\mathrm{CMV}$ & not recommended & $\begin{array}{l}\text { maternal blood IgG and IgM (paired sera and } \\
\text { avidity) and PCR for CMV; amniotic fluid PCR } \\
\text { for CMV DNA; amniocentesis } 6 \text { weeks after } \\
\text { infection or at }>21 \text { weeks of gestation; } \\
\text { cordocentesis/fetal blood for viral load/platelet } \\
\text { count at }>21 \text { weeks of gestation; consider genetic } \\
\text { testing if indicated (karyotype or CMA) }\end{array}$ & $\begin{array}{l}\text { US: abdominal/intrauterine } \\
\text { growth restriction/ hydrops/ } \\
\text { placenta }\end{array}$ & $\begin{array}{l}\text { fetal infection; } 30-40 \% \\
\text { with primary infection, } \\
1-2 \% \text { with nonprimary } \\
\text { infection; more } \\
\text { common in later } \\
\text { gestation, but less severe }\end{array}$ \\
\hline Parvovirus B19 & not recommended & $\begin{array}{l}\text { maternal blood IgG and IgM (paired sera); } \\
\text { amniotic fluid PCR for parvovirus B19 DNA; } \\
\text { amniocentesis at }>18 \text { weeks of gestation; } \\
\text { cordocentesis/fetal blood fetal anemia/post } \\
\text { MCA value; consider genetic testing if indicated } \\
\text { (karyotype or CMA) }\end{array}$ & $\begin{array}{l}\text { MCA velocity monitoring } \\
\text { for fetal anemia screening; } \\
\text { US: hydrops/cardiac/pleural } \\
\text { effusions }\end{array}$ & $\begin{array}{l}\text { fetal infection across all } \\
\text { three trimesters, but } \\
\text { greater risk in early } \\
\text { pregnancy ( } 10 \% \text { fetal } \\
\text { loss/3\% fetal hydrops) }\end{array}$ \\
\hline Toxoplasma & not recommended & $\begin{array}{l}\text { maternal blood IgG and IgM (paired sera and } \\
\text { avidity); amniotic fluid PCR for Toxoplasma } \\
\text { DNA; amniocentesis } 5 \text { weeks after infection or } \\
\text { at }>18 \text { weeks of gestation; consider genetic } \\
\text { testing if indicated (karyotype or CMA) }\end{array}$ & $\begin{array}{l}\text { US: hydrops/pleural or } \\
\text { pericardial effusions/ } \\
\text { abdominal }\end{array}$ & $\begin{array}{l}\text { fetal infection first } \\
\text { trimester } 5-15 \% / \text { third } \\
\text { trimester } 70-80 \%\end{array}$ \\
\hline Varicella & $\begin{array}{l}\text { varicella IgG; if } \\
\text { nonimmune, provide } \\
\text { nonpregnant vaccination } \\
\text { and delay conception } \\
4 \text { weeks }\end{array}$ & $\begin{array}{l}\text { maternal IgG and IgM (paired sera); maternal } \\
\text { skin vesicular lesion fluid for PCR; consider } \\
\text { genetic testing if indicated (karyotype or CMA) }\end{array}$ & $\begin{array}{l}\text { US: polyhydramnios/ } \\
\text { placentomegaly/calcifications/ } \\
\text { hydrops }\end{array}$ & $\begin{array}{l}\text { fetal infection occurs in } \\
10-15 \% \text { of maternal } \\
\text { chickenpox/first } 20 \\
\text { weeks varicella } \\
\text { syndrome } 1 \%\end{array}$ \\
\hline
\end{tabular}

CMA, chromosomal microarray; CMV, cytomegalovirus; MCA, middle cerebral artery; US, ultrasound.

ing findings leading to maternal-fetal STORCH testing were intrauterine growth restriction (30.4\%) including microcephaly (1.5\%), polyhydramnios (14.8\%), and intrauterine death (IUD) (13.3\%). Intracranial or abdominal echogenicity was rare in this cohort. Maternal STORCH infections were found in $3.4 \%$ of intrauterine growth restriction, $5.2 \%$ of polyhydramnios, and $1.9 \%$ of IUD with CMV (7), parvovirus B19 (6), varicella (1), and enterovirus (1) [26].

Viral invasion of the amniotic fluid cavity has been identified in asymptomatic women undergoing midtrimester amniocentesis. The amniocentesis cohort of 729 women with no fetal or chromosomal anomalies and clinical follow-up had PCR screening of their amniotic fluid for six common viral genomes (adenovirus, herpes simplex virus, varicella zoster virus, human herpesvirus 6, human CMV [HCMV], Epstein-Barr virus, parvovirus B19, and enterovirus). Viral genome was found in 16 of the 729 (2.2\%) amniotic fluid samples (human herpesvirus 6 [7], HCMV [6], parvovirus B19 [2], and EpsteinBarr virus [1] with no cases of herpes simplex virus, varicella zoster virus, enterovirus, or adenovirus). Corresponding viral DNA was found in 6 of 7 maternal blood samples with human herpesvirus 6-positive amniotic fluid and in one umbilical cord plasma sample [27]. Table 1 summarizes the US and MRI features (head, thorax, cardiac, abdominal, amniotic fluid, and placental) for identified fetal infections $[6,26,28,29]$.

\section{Question 4}

Maternal knowledge and informed consent for investigation and diagnosis are critical for a presumed or confirmed perinatal viral infection.

Table 2 provides a limited summary for a maternal counseling and diagnostic management pathway $[1,28$, 30]. The indications and risks for maternal and fetal assessment by diagnostic procedures in pregnancies with an "at-risk" perinatal infection include counseling and testing factors such as maternal serology to identify a probable infectious organism, US/MRI imaging assessment identifying possible fetal and placental infectious exposure, fetal loss risks secondary to viral exposure alone, determination of the gestational age at fetal exposure and the estimated length of viral exposure at the time of infectious evaluation testing and/or diagnostic procedure date, use of appropriate fetal infectious diagnostic 
tests including genetic testing if indicated, and the fetal loss risks related to the appropriate diagnostic procedure(s).

The spontaneous fetal loss rate (first to second trimester) with a documented perinatal viral infection (positive or negative fetal anomalies) and no fetal diagnostic procedure is poorly defined. While certain factors are clearly associated with spontaneous fetal loss (hormonal-ovulatory, genetic, uterine anomalies), the relationship between pregnancy loss and viral infections remains controversial. Evaluation of embryonic and early fetal loss as well as using maternal serology/PCR and products of conception PCR report both positive and negative associations [31-36]. Recent congenital CMV guidelines for prevention, diagnosis, and therapy provide no information related to miscarriage rates with first to second trimester CMV infection [37, 38].

A CMV cohort study (2009-2017) analyzed 4,125 women and newborns, after exclusion of 459 (7.1\%) spontaneous miscarriages. Newborns had urine testing by PCR for CMV DNA, with 9 positive results. The maternal pregnancy characteristics for the 9 positive cases were compared with the 4,116 maternal controls and identified increased multivariate logistic regression analysis ORs for threatened miscarriage-preterm labor in the second trimester (OR 6.0, 95\% CI 1.6-22.8) and fever or flu-like symptoms (OR 17.9, 95\% CI 3.7-86.7). These clinical factors were $100 \%$ sensitive and $53 \%$ specific for a CMV-associated pregnancy impact [39].

A retrospective periconceptional primary maternal CMV cohort of 59 cases with a median gestational age at diagnosis of 8 (4-11) weeks had a spontaneous abortion loss rate of 7\%. Amniocentesis was undertaken in 43 patients, with a $25.5 \% \mathrm{CMV}$-positive rate, and no pregnancy losses were reported [40]. A prospective primary CMV study (7 years) reported that fetal loss occurred in 15\% $(4 / 26)$ of early CMV infections compared to a rate of $2.2 \%$ $(16 / 744)$ in controls [41].

The outcomes for fetuses with congenital parvovirus B19 (SR/MA) identified increased miscarriage rates when comparing hydropic and nonhydropic parvovirus B19infected fetuses (pooled proportion hydropic fetus $27.2 \%$ (95\% CI 12.2-45.5\%) compared to nonhydropic fetus $8.8 \%$ (95\% CI $2.8-17.6 \%)$ with a pooled OR of $11.5(95 \%$ CI 2.7-49.7) [42].

The seroprevalence of toxoplasmosis (IgG, IgM) antibodies in women who had experienced a spontaneous abortion identified with pooled ORs that the toxoplasmosis IgG/IgM seroprevalence was higher than in controls (IgG: OR 1.65, 95\% CI 1.31-2.09; IgM: OR 2.26, 95\% CI

Perinatal Infection and Intrauterine Testing
1.56-3.28). The study conclusion reported that perinatal toxoplasmosis could be a possible factor for maternal spontaneous abortion [43].

Sauerbrei and Wutzler [44] reported that the rate of spontaneous abortion following acute varicella infection did not exceed the rate of abortion in pregnant women without chickenpox. A prospective study reported on the outcome of 1,373 pregnancies with maternal varicella, based on the gestational weeks of varicella exposure. Varicella exposure at $0-16$ weeks (from last menstrual period) resulted in $2.7 \%$ miscarriages $(36 / 1,330)$ in addition to 43 pregnancy terminations. IUD occurred in $0.7 \%$ $(9 / 1,330)$ and was equally distributed across the $0-36$ gestational weeks (from last menstrual period). The 9 cases of congenital varicella were all exposed at $<20$ weeks, with 7 fetal exposures between 13 and 20 weeks ( $2.0 \%$ risk) and 2 fetal exposures at $<13$ weeks ( $0.4 \%$ risk) [45].

The evaluation of a "complex pregnancies" cohort requiring amniocentesis after 24 weeks of gestation for a number of indications (perinatal infection, lung maturity, therapeutic procedures, genetic testing) is summarized in Geffen et al. [19]. Even though only 7\% of the procedures had an infectious indication, the second trimester amniocentesis gestational age of $>24$ weeks is important for analysis, as the outcomes are useful for the informed consent process. There were 285 amniocentesis procedures undertaken, but only 167 cases could be analyzed. While the procedure indications were varied, the mean gestational age at amniocentesis was approximately 32 weeks (range 24-37), with 104 procedures at 24-32 weeks and 63 procedures at $>32$ weeks. The mean gestational age at delivery was 38.3 weeks $( \pm 2.7)$ and latency from amniocentesis to delivery $<1$ week was $7 \%$ [19].

Daum et al. [46] evaluated a "late" amniocentesis procedure cohort (24-38 ${ }^{+6}$ weeks), 291 women (303 fetuses; 277 singletons, 14 twin pairs; in two twin pairs, one fetus was terminated before amniocentesis), with the most frequent indication being fetal anomalies (67\%). Chromosomal microarray was used to identify the fetal genetic pathology (fetal aneuploidy [3\%] and copy number variants [3\%]). There were no preterm births in the cohort that had no fetal structural or US abnormalities. GabbayBenziv et al. [47] evaluated a third-trimester amniocentesis cohort (mean gestational age $31.6 \pm 2.3$ weeks) of 168 women. The amniocentesis indication was suspected infection (23), abnormal US findings (120), and genetic risks (21). One of the 23 pregnancies with an infectious risk was $\mathrm{CMV}$-positive and required cesarean delivery (33 weeks of gestation) within 1 week of the amniocentesis procedure. There were a total of 13 preterm deliveries, 
Table 3. Prenatal diagnostic procedures in infected maternal pregnant cohorts [48-56]

\begin{tabular}{|c|c|c|c|}
\hline Reference & $\begin{array}{l}\text { Infection } \\
\text { cohort }\end{array}$ & Study, time period, location & Unintended pregnancy loss and VT summary \\
\hline Weisz et al. [48], 2011 & varicella & retrospective study (2001-2007), Israel & $\begin{array}{l}\text { AC in } 19 / 20 \text { cases at a mean of } 22.2 \pm 1.7 \text { weeks with a mean infection age of } 11 \pm 3.5 \text { weeks; no } \\
\text { postprocedural losses reported; no VT reported }\end{array}$ \\
\hline Mouly et al. [49], 1997 & varicella & $\begin{array}{l}\text { prospective cohort, } 1989-1994 \text {, France; congenital varicella } \\
2.8 \% \text { (3/107); postnatal varicella zoster infection } 3.8 \%(3 / 78)\end{array}$ & $\begin{array}{l}\text { AC 107; FBS 82; procedures at } 21-26 \text { weeks of gestation; AC with positive viral AF PCR was identified } \\
\text { in } 9 / 107 \text { ( } 8.4 \% \text { ) with maternal infection at }<24 \text { weeks; single IUD after AC (negative prenatal testing); } \\
\text { no procedure-related VT }\end{array}$ \\
\hline Lipitz et al. [50], 2020 & HCMV & prospective study, 2011-2018, Israel & $\begin{array}{l}\text { VT was identified by AC in } 123 \text { patients with primary CMV infections; US findings } 30.9 \% \text {; MRI } \\
\text { abnormalities } 30.1 \% \text { at } 32-34 \text { weeks; } 15 \text { TOP; no loss associated with AC }\end{array}$ \\
\hline $\begin{array}{l}\text { Hawkins-Villarreal } \\
\text { et al. [51], } 2019\end{array}$ & HCMV & prospective study, 2006-2018, Spain & $\begin{array}{l}\text { FBS in } 28 \text { CMV-infected fetuses considered severely or mildly affected according to prenatal US/MRI } \\
\text { brain damage; US/MRI abnormalities in } 43 \text { pregnancies/44 fetuses; severe: } 29 / 29 \text {, FBS } 20 \text {, TOP } 19 \text {, } \\
\text { STOP } 1 \text {; no/mild: } 16 / 17 \text {, FBS } 8 \text {, TOP 3, IUD 1, LB 4; risk allocation not possible due to small cohort }\end{array}$ \\
\hline Simonazzi et al. [52], 2017 & HCMV & $\begin{array}{l}\text { prospective observational cohort referred with primary } \\
\text { HCMV, } 2007-2014 \text {, Italy; } 606 \text { patients with primary HCMV; } \\
239 \text { enrolled (189 declined; } 40 \mathrm{GA}<12 \text { weeks [6.6\%]; } 2 \text { age } \\
<18 \text { years; } 40 \text { immuno Rx; } 96 \text { lost to follow-up) }\end{array}$ & $\begin{array}{l}\text { AC: } 239 \text { with prior maternal blood for HCMV DNA; primary infection definition: seroconversion } \\
\text { or + IgM and low/moderate + IgG; AC }>20 \text { weeks and }>6 \text { weeks after maternal infection; maternal } \\
\text { DNA viremia: positive } 32(13.4 \%) \text {, negative } 207(86.6 \%) \text {; no post-AC unintended loss reported; VT: } \\
\text { a maternal viral DNA result was associated with an OR of } 3.06 \text { ( } 95 \% \text { CI 1.41-6.64), but iatrogenic } \\
\text { procedure risks were ruled out }\end{array}$ \\
\hline Enders et al. [53], 2017 & HCMV & $\begin{array}{l}\text { retrospective single-center study, 2010-2014, Germany; } 132 \\
\text { pregnancies with primary infection; } 27 \text { abnormal US, } 105 \\
\text { normal US; } 117 \text { AC and FBS, } 11 \text { AC only, } 4 \text { FBS only; } 17 \text { lost } \\
\text { to follow-up (15 AC-FBS, } 2 \text { AC) }\end{array}$ & $\begin{array}{l}115 \text { pregnancies with primary CMV infection, AC 111, FBS 106; unintended loss } 1 \text { (TOP); no } \\
\text { procedure-related VT; abnormal US: CMV - +, no 9/9, infected 16/16; normal US: CMV - +, no } \\
\text { 58/70, infected 19/20; total infected: } 47 / 115(41 \%)\end{array}$ \\
\hline Revello et al. [54], 2008 & HCMV & $\begin{array}{l}\text { prospective primary HCMV maternal infection and AC } \\
\text { risk contributing to VT to the fetus, Italy; AF negative for } \\
\text { HCMV DNA in } 37 \% \text { of women with viremia; AF positive } \\
\text { for HCMV DNA in } 37 \% \text { of women with viremia; } 8 \text { with } \\
\text { false-negative AF testing had } 4 \text { maternal viremia positivity } \\
\text { and } 4 \text { viremia negativity }\end{array}$ & $\begin{array}{l}194 \text { pregnant women with primary HCMV infections and } 199 \text { fetuses; congenital HCMV was } \\
\text { diagnosed in } 38 \% \text { ( } 76 / 199) \text { of fetuses; conclusion: maternal HCMV DNA viremia was not associated } \\
\text { with risk of VT at the time of AC }\end{array}$ \\
\hline Donadono et al. [55], 2019 & Toxoplasma & population-based cohort study, 2001-2012, Italy & $\begin{array}{l}\text { seroconversion and suspected infection in pregnancy } 0.8 \text { per } 1,000 \text { live births; congenital } \\
\text { toxoplasmosis } 0.1 \text { per } 1,000 \text { live births; seroconversion: total } 183 \text {, AC } 89 \text {, positive } 24.7 \% \text {, follow-up } \\
157 \text {, miscarriage } 2(1.3 \%) \text {; suspected infection: total } 381 \text {, AC } 167 \text {, positive } 15 \% \text {, follow-up } 319 \text {, } \\
\text { miscarriage } 13(4.1 \%)\end{array}$ \\
\hline Findal et al. [56], 2017 & Toxoplasma & $\begin{array}{l}\text { retrospective study, } 1993-2013 \text {, Norway; } 173(50 \%) \\
\text { infected prior to pregnancy; } 80(23 \%) \text { possibly infected in } \\
\text { pregnancy; } 93(27 \%) \text { infected during pregnancy }(49[14 \%] \\
\text { seroconverted, } 42[12 \%] \text { increasing IgG, } 255[74 \%] \text { had } \\
\text { positive IgM and low IgG) }\end{array}$ & $\begin{array}{l}346 \text { singleton pregnancies undergoing AC due to suspected maternal primary toxoplasmosis at a } \\
\text { mean of } 16.7 \text { gestational weeks; unintended loss } 2 / 346(0.6 \%) \text { (both were early AC at } 13 \text { weeks); } \\
\text { no procedure-related VT; } 15 / 332(4.3 \%) ; 15 \text { neonatal infections ( } 4.3 \%) \text { (14 positive AF PCR, } \\
1 \text { negative AF PCR }[0.3 \%])\end{array}$ \\
\hline
\end{tabular}

AC, amniocentesis; AF, amniotic fluid; FBS, cordocentesis; GA, gestational age; HCMV, human cytomegalovirus; IUD, intrauterine death; LB, liveborn; MRI, magnetic resonance imaging; STOP, surgical ter mination of pregnancy; TOP, termination of pregnancy; US, ultrasound; VT, vertical transmission.

indicating a postprocedure preterm delivery risk of $8 \%$ (13/168).

Invasive diagnostic procedures at $>22-24$ weeks of gestation have an increased risk for preterm delivery of $7-8 \%$ mainly associated with preexisting fetal congenital and amniotic fluid abnormalities. The possibility of an increased preterm birth mechanism associated with intrauterine viral infection in the late second and third trimester alone has limited data to support this perinatal risk $[19,46,47]$.

\section{Question 5}

Table 3 summarizes the published literature for maternal infection cohorts and the outcomes for unintended fetal loss and evaluations to determine the possibility of fetal VT [48-56]. The "pooled" procedure-related fetal loss risk estimate for infectious diagnostic amniocentesis procedures is estimated at $1.5 \%(18 / 1,187)-0.8 \%$ from varicella (1/127), $0 \%$ from HCMV (0/458), and $2.8 \%$ from toxoplasmosis (17/602). The cordocentesis procedure risk from infected cohorts could not be determined with varicella $(0 / 82), \operatorname{HCMV}(0 / 106)$, and in one prospective series of 28/28 fetuses prior to pregnancy termination. While the unintended amniocentesis fetal loss rates are from small infected population cohorts, the pooled or individual risks could be used for counseling purposes. The risk of fetal VT in the acute infection cohort's secondary to the intra-amniotic diagnostic procedure was not increased.

The biological VT to the fetus for CMV appears to be increased with a positive maternal viremia (OR 3.06, 95\% CI 1.41-6.64) [52] and the transmission evidence with the identification of fetal "disruptive" anomalies by US [54]. A negative (undetected) maternal CMV viremia result has a reported viral VT rate of $15-20 \%$ [52, 53]. In a retrospectively analyzed amniocentesis cohort with suspected toxoplasmosis infection, a spontaneous transplacental VT rate of $4.5 \%(15 / 332)$ was associated with a positive amniotic fluid viral PCR result (14/15 cases) [56]. Amniocentesis was not associated with an increased VT risk [48, 49, 52-54, 56]. 
Varicella infection and VT risks has been analyzed. Enders et al. [45] reported prospectively on a "nonintrauterine diagnostic procedure" cohort of 1,373 pregnant women with a varicella infection prior to 36 weeks of gestation. There were 43 therapeutic terminations, leaving 1,330 pregnancies to be followed. Spontaneous abortions prior to 16 weeks of gestation occurred in 36 women (3\%). Among the 1,294 continuing pregnancies, there were 9 fetal deaths $(0.7 \%)$ after 20 weeks of gestation (1 case had severe congenital varicella syndrome infection). Cord blood or venous samples were obtained shortly after birth for varicella IgM antibody analysis. There were 1,285 pregnancies intended to continue to term, with 1,291 liveborn infants. Based on gestational age at maternal infection, there were 9 affected infants identified and the rate of viral transmission (maternal to fetal) was $2 / 472$ $(0.4 \%)$ at $0-12$ weeks and $7 / 351(2.0 \%)$ at $13-20$ weeks, while for exposure after 20 weeks (477 cases between 21 and 36 weeks) there were no varicella-affected infants, with 3 losses (therapeutic abortion/IUD/IUD) for pregnancies continuing past 20 weeks of gestation.

The risk assessment of CMV-infected fetuses symptomatic at birth is predictable at the time of diagnosis by use of a combination of targeted US assessment (cerebral and extracerebral findings) along with a higher viral load (CMV DNA) identified in amniotic fluid and fetal blood $(\geq 4.93$ $\left.\log _{10} \mathrm{IU} / \mathrm{mL}\right)$ and with a fetal blood platelet count $(<114,000 /$ $\mathrm{mm}^{3}$ ). Diagnostic procedure fetal loss rates were not provided in the publications [57, 58]. Hawkins-Villarreal et al. [51] reported on 46 pregnancies/47 fetuses with 28 cordocenteses ( 20 severe/ 8 nonsevere features) in the second and third trimester. The majority of the cordocenteses (78\%) were done at the time of pregnancy termination. BlázquezGamero et al. [59] reported on the outcomes of 36 pregnant women with primary CMV infections. An amniocentesis for CMV PCR was performed at least 6 weeks after a positive serological result and once the pregnancy had reached 21 weeks of gestation. There were 17 pregnancies in the prevention group with 16 liveborns and 1 pregnancy termination (abnormal cordocentesis result) and 19 pregnancies in the treatment group with 19 liveborns.

\section{Discussion}

The prevalence of perinatal infections (per 100,000 population) is estimated at 800 for CMV, 250 for parvovirus B19, 10-33 for toxoplasmosis, and vaccine-dependent for varicella. CMV is the most common perinatal viral infection, with $1-4 \%$ of seronegative pregnant wom-

Perinatal Infection and Intrauterine Testing en acquiring an asymptomatic infection with primary maternal CMV, leading to $40 \%$ fetal infection. Parvovirus B19 evaluation shows that $50-70 \%$ of reproductive-aged women have developed immunity to parvovirus B19, and seronegative women are estimated to have a $1-3 \%$ risk of serological conversion in pregnancy. When fetal hydrops is identified by US, consider maternal assessment for parvovirus B19. Toxoplasmosis is estimated to affect $2-3$ per 1,000 pregnancies. Toxoplasmosis exposure from foodborne disease is the third most common cause after salmonella and listeriosis. It is estimated that $15 \%$ of childbearing-aged women (15-44 years) in the USA are infected with Toxoplasma gondii annually. Varicella has both fetal and neonatal effects. The neonatal risk is greatest with late gestational exposure (maternal rash 5 days before delivery to 2 days after birth). Source references for the perinatal infection diagnosis and management are provided [30, 37, 38, 57, 60-73].

Maternal serology evaluation and fetal imaging investigations are an important component in the fetal risk assessment pathway $[1,28,30]$. Imaging of the fetal central nervous system for possible "infectious disruptive" insult is important for maternal counseling as viral activity interferes with normal fetal brain development, resulting in neuronal migration abnormalities, cortical disorganization, and altered white matter myelination with increased neonatal morbidity. The central nervous system disruption secondary to the infectious insult is related to both the primary insult caused by the pathogen-specific endotoxins and the host's inflammatory response. The fetal brain is particularly sensitive to neurotropic organisms, especially in the first and second trimesters [29].

For fetal CMV infection, the gold standard for diagnosis is amniotic fluid PCR for CMV DNA (following documentation of maternal primary CMV exposure) or fetal "disruptive" anomalies following US or MRI imaging with increased sensitivity after 21 weeks of gestation or 6 weeks after CMV infection. Maternal CMV IgG antibody seroconversion is diagnostic for primary CMV infection and maternal CMV IgM antibody is present as well, but IgM can be produced in nonprimary infections and false positives are common. Maternal IgG avidity testing is important as only low- to moderate-avidity IgG antibodies are produced in the first 12 weeks after the primary infection $[1,28,30]$.

For fetal parvovirus B19 infection, the gold standard for diagnosis is amniotic fluid PCR for parvovirus B19 DNA and US imaging features of fetal "disruptive" anomalies. For parvovirus B19 maternal IgM and IgG antibodies are produced, and the IgM antibody response persists for one to several months, identifying a recent infection, 
while IgG antibodies (lifelong immunity) without IgM indicate a prior infection. Stillbirth secondary to maternal parvovirus B19 infection has been reported from 1 to 11 weeks after infection, while hydrops is unlikely to occur $>8$ weeks after infection $[1,28,30]$.

For fetal toxoplasmosis, the gold standard for diagnosis is amniotic fluid PCR for Toxoplasma DNA and imaging for fetal "disruptive" anomalies, with testing after 18 weeks of gestation and 5 weeks after infective exposure. IgM antibodies may persist for $>12$ months and false-positive results are common. IgG avidity testing requires laboratory-specific cutoffs, but low avidity is indicative of primary infection within the past 5 months $[1,28,30]$.

For fetal varicella exposure, maternal clinical features are directive for a chickenpox diagnosis. Maternal skin lesions can be used for viral PCR or immunofluorescence testing as the diagnostic gold standard of exposure. In addition, fetal imaging for evidence of fetal "disruptive" anomalies is important for risk-benefit counseling $[1,9]$.

Diagnostic fetal genetic testing should be considered when indicated; with a previous pregnancy or family genetic history risk, maternal aneuploidy screening (by serum analytes or cell-free placental DNA/noninvasive prenatal screening) is offered, and fetal structural anomalies are present (not associated with the possible infectious exposure). If fetal structural malformations are identified, chromosomal microarray is recommended, as more clinically significant information is provided compared to a fetal karyotype. Whole-exome sequencing is not usually indicated unless normal fetal karyotype and chromosomal microarray results are present and multiple congenital anomalies unrelated to infectious exposure have been identified [74-77].

There are several factors that contribute to why patients may decline amniocentesis. Significant factors identified include the number of previous miscarriages, maternal educational background, reported nuchal translucency values, and personalized maternal risk scores/ screening for fetal aneuploidy. These maternal factors need to be taken into consideration during the counseling process as additional genetic, infection, and associated US-identified fetal anomalies could contribute to both maternal risk and benefit considerations [78].

In a recent randomized controlled trial, pregnant women identified to have pregnancies with a high risk of trisomy 21 by aneuploidy screening were subsequently compared for the risk of miscarriage based on a "diagnostic testing" process of either obtaining a maternal plasma cell free placental DNA result and if positive undergoing invasive testing or an immediate invasive testing procedure (amniocen- tesis or chorionic villus sampling) [79]. This study was designed to compare miscarriage rates between the two "trisomy 21 diagnostic" processes, but no significant miscarriage rate difference was identified in either group $(0.8 \%$ in both groups) where invasive testing occurred in $84(8.3 \%)$ of the cell-free placental DNA followed by invasive diagnostic testing with screen positive result cohort and in 751 $(76.5 \%)$ of the immediate invasive diagnostic testing cohort. The authors stated that the study may have been underpowered to detect clinically important differences in miscarriage rates. This study is not helpful in identifying an invasive fetal procedure risk as there were numerous study limitations (57 centers involved, lack of protocol adherence [17\% declined randomization and $24 \%$ allocated to invasive testing refused their allocation]) and no evaluation of a "no procedure" cohort [79].

Tabor et al. [80] reported from their randomized controlled trial evaluating amniocentesis versus "no invasive procedure" cohorts an increased risk of miscarriage of $1 \%$ in the procedure group (95\% CI $0.3-1.5)$. This postprocedure fetal loss rate outcome was highly criticized [20]. They subsequently reported on a cohort of 32,852 amniocentesis procedures (1996-2006), with a total postprocedure fetal loss rate of $1.4 \%$ (95\% CI 1.3-1.5). Provider procedure experience was identified as an important factor in the total fetal loss rate. Retrospective postamniocentesis reviews $[16,18]$ have reported an added $1 \%$ fetal loss risk for a second-trimester amniocentesis procedure with comparison to a "no procedure" group, but the continued use of the 1986 Tabor randomized controlled trial fetal loss rate of $1 \%$ [20] has been challenged [18].

The majority of diagnostic procedures are limited to amniocentesis and, in selected infections such as CMV, cordocentesis (Table 3) [48-56]. The total fetal risk related to amniocentesis in infected cohorts is estimated at $1.5 \%$. This infected fetal loss rate is consistent with the noninfected "procedure only" fetal loss risk range of $0.11-0.35 \%$ added to the "background spontaneous" fetal loss risk of $0.7 \%$ for a total estimated risk of $1 \%$ [9-19]. The two most recent SRs/MAs have the "noninfected" procedure amniocentesis risk estimated at $0.30-0.35 \%[9$, 10]. The "no procedure" rate of miscarriage (with post $12-14$ weeks of gestation viability) is reported at $0.65-$ $0.70 \%[11-15,20,21]$. The cordocentesis procedure risk in complex noninfected cohorts was variable and based on the fetal physiology at the time of the procedure (fetal anemia $2.0 \%$, no hydrops $3.2 \%$, immune fetal hydrops $9.1 \%$, nonimmune fetal hydrops $31.7 \%$ ) [23-25].

It is possible that there is an increased preterm birth mechanism associated with intrauterine viral infection in 
the late second and third trimester, but there are limited data to report on this potential perinatal risk.

The viral mechanistic basis of VT across the placental barrier is unclear [81]. A study of VT in human pregnancy using animal and cell culture models was not able to provide a detailed understanding of the barriers used by the human placenta. While it is possible that the perinatal organisms may employ a common mechanism for invasion, it is more likely that each organism has evolved distinct invasion strategies dependent on gestational age and maternal responses to the infection [81].

In a review of fetal varicella syndrome (FVS), Mandelbrot [82] commented that the mother to child transmission increases with gestation age based on neonatal IgM antibody values, although some infected fetuses/neonates did not produce specific IgM and most FVS cases were reported as asymptomatic. The overall prevalence of FVS, with exposure prior to 20 weeks of gestation, was estimated at $1.0 \%$. Risk factors identified for FVS are gestational age at exposure, maternal IgG antibodies, and pathogen/host-related response. More data related to viral transmission and the level of maternal viremia are required. Female fetuses have been shown to have an increased risk of transmission with exposure for HIV, hepatitis $\mathrm{C}$ virus, and $\mathrm{CMV}$ infections [82].

A "potential" infectious VT risk from maternal blood contamination following an amniocentesis procedure was reported by Giorlandino et al. [83]. Amniotic fluid was collected in 20 patients undergoing a second amniocentesis, within 2 weeks of the first procedure, and was compared to that of a control group of 20 patients having their first procedure. At the repeat procedure, all patients with a primary transplacental procedure had blood-stained taps, but $4 / 9(44 \%)$ with a nonplacental procedure had blood-stained taps as well. In the control group all fluid specimens were clear, regardless of the placental location. This clinical finding directs a recommendation that the placenta or placental edges be avoided during a maternal "at-risk" infection amniocentesis and that continuous observation with postprocedure US should be used to assess for uterine/maternal bleeding after needle removal.

Fetal CMV cohorts have had more extensive evaluation considering prevention, treatment, and feasibility of outcome prediction with the use of amniocentesis and cordocentesis in both the diagnostic and predictive pathways. Maternal perception of CMV infection during pregnancy indicates that the majority of patients had no knowledge of CMV risks. Maternal choice, with CMV exposure only or mild US findings, led to abortion or no further testing [84].

Perinatal Infection and Intrauterine Testing
A CMV "state of the science" guideline is comprehensive [85]. The natural history of neonates infected with CMV following a maternal primary infection results in symptomatic outcomes ( $12.7 \%$ with $3-4 \%$ deaths) and asymptomatic outcomes ( $87.3 \%$ with $86.5 \%$ having no sequalae). Recommended management requires amniocentesis after 17 weeks and 8 weeks after the presumed date of primary infection. For those cases with positive amniotic fluid CMV PCR, maternal management should include valaciclovir $8 \mathrm{~g} /$ day until delivery, cordocentesis at 20 weeks for fetal platelet count and CMV/DNA level, US every 2 weeks until delivery, and fetal brain MRI at 32 weeks [85]. Negative results from amniotic fluid CMV PCR and shell viral assay did not completely rule out a neonatal infection with clinical morbidity [86].

The knowledge gaps for acute perinatal infections are large. CMV cohorts have focused activity in a number of perinatal units for screening, diagnosis, and treatment, but there is very little published activity for other perinatal infections. The ability to create prospective case-control infected cohorts for parvovirus B19 and toxoplasmosis (and in vaccine-limited areas/countries for varicella) requires multidisciplinary collaboration, focused interest, data management, specimen banking, and funding. The decreasing numbers of diagnostic procedures due to genomic cell-free placental DNA screening for aneuploidy presents an opportunity as perinatal infections require invasive fetal testing of amniotic fluid, fetal blood, and placental infection assessment. Preterm delivery has little information related to the contribution from viral infection. Fetal therapy for viral infection requires early recognition, innovation, and multidisciplinary activity (infectious disease, neonatology, pathology lab medicine, maternal-fetal medicine, multiple'omics). The large amount of fetal therapy activity for structural fetal/placental abnormalities (myelomeningocele, twin to twin transfusion, congenital diaphragmatic hernia, congenital heart disease, lower urinary tract obstruction) and maternal therapy for preeclampsia limits the maternal-fetal medicine human resources for other perinatal investigations. Finally, the lack of appropriate annual support for public health and infection surveillance from national sources has been clearly identified with the COVID-19 pandemic.

\section{Conclusions}

Acute maternal viral infection during pregnancy requires identification of the virus, the viral infectious anatomical location(s), and the potential viral disruptive ac-

Fetal Diagn Ther 2020;47:653-664 
tivity in the fetus for patient counseling and an informed consent process. The prevalence of acute viral/nonviral perinatal maternal infections (per 100,000) is estimated at 800 for CMV , 250 for parvovirus B19, 10-33 for toxoplasmosis, and vaccine-dependent for varicella, as the most common organisms.

The unintended total "fetal loss" rate of 1.5\% after amniocentesis in an infected cohort appears to be similar to the "separated and additive" amniocentesis fetal loss risk in the "noninfected" cohorts of the procedure-only risk range $0.11-0.35 \%$ ( 1 per $285-900$ ) added to the background spontaneous risk range of $0.65-0.70 \%$ ( 1 per 140 150). The cordocentesis procedure risk in infected cohorts is associated with the fetal physiology at the time of the procedure ( $2-32 \%$ fetal loss). There appears to be an increased risk for preterm delivery for amniocentesis undertaken after 22-24 weeks of gestation.

The majority of viral VT risk is related to vascular, placental (including factors associated with maternal fetal bleeding), specific infectious pathogen, gestational age at exposure, and possible female fetal status factors. The spontaneous variable maternal-fetal VT rates are biologically based (CMV 44\% with maternal viremia/20\% with no identified maternal viremia, varicella $8 \%$, toxoplasmosis $4 \%$ ).

No associated viral VT risk was identified by amniocentesis, but postprocedure observation for maternal blood contamination of the amniotic cavity is required.

Maternal knowledge translation, an informed consent process, and maternal/fetal risk-benefit counseling is necessary prior to amniocentesis or other diagnostic/ therapeutic intrauterine procedures.

\section{Statement of Ethics}

This is a literature review and no ethics approval was required.

\section{Disclosure Statement}

The author has no conflicts of interest to declare.

\section{Funding Sources}

There are no funding sources to declare.

\section{References}

1 Keighley CL, Skrzypek HJ, Wilson A, Bonning MA, Gilbert GL. Infections in pregnancy. Med J Aust. 2019 Aug;211(3):134-41.

2 Khan AM, Morris SK, Bhutta ZA. Neonatal and Perinatal Infections. Pediatr Clin North Am. 2017 Aug;64(4):785-98.

3 Beigi RH. Emerging Infectious Diseases in Pregnancy. Obstet Gynecol. 2017 May;129(5): 896-906.

4 Vygivska LA, Tuchkina IO, Kalnytska VB. The impact of emergent infections on the fetal state. Wiad Lek. 2017;70(4):731-6.

5 Racicot K, Mor G. Risks associated with viral infections during pregnancy. J Clin Invest. 2017 May;127(5):1591-9.

6 Neu N, Duchon J, Zachariah P. TORCH infections. Clin Perinatol. 2015 Mar;42(1):77103.

7 Kadambari S, Pollard AJ, Goldacre MJ, Goldacre R. Congenital viral infections in England over five decades: a population-based observational study. Lancet Infect Dis. 2020 Feb;20(2):220-9.

8 Neumann I, Schünemann HJ. Guideline groups should make recommendations even if the evidence is considered insufficient. CMAJ. 2020 Jan;192(2):E23-4.

9 Salomon LJ, Sotiriadis A, Wulff CB, Odibo A, Akolekar R. Risk of miscarriage following amniocentesis or chorionic villus sampling: systematic review of literature and updated meta-analysis. Ultrasound Obstet Gynecol. 2019 Oct;54(4):442-51.
10 Beta J, Lesmes-Heredia C, Bedetti C, Akolekar R. Risk of miscarriage following amniocentesis and chorionic villus sampling: a systematic review of the literature. Minerva Ginecol. 2018 Apr;70(2):215-9.

11 Bakker M, Birnie E, Robles de Medina P, Sollie KM, Pajkrt E, Bilardo CM. Total pregnancy loss after chorionic villus sampling and amniocentesis: a cohort study. Ultrasound Obstet Gynecol. 2017 May;49(5): 599-606.

12 Özcan HC, Uğur MG, Sucu S, Mustafa A, Bayramoğlu Tepe N, Balat Ö. Summary of 2185 prenatal invasive procedures in a single center: A retrospective analysis. Turk J Obstet Gynecol. 2017 Jun;14(2):114-20.

13 Wulff CB, Gerds TA, Rode L, Ekelund CK, Petersen OB, Tabor A; Danish Fetal Medicine Study Group. Risk of fetal loss associated with invasive testing following combined first-trimester screening for Down syndrome: a national cohort of 147,987 singleton pregnancies. Ultrasound Obstet Gynecol. 2016 Jan; 47(1):38-44.

14 Theodora M, Antsaklis A, Blanas K, Antsaklis P, Daskalakis G, Sindos M, et al. Risk for fetal loss and prematurity after 12,413 second trimester amniocenteses in a single center. J Perinat Med. 2015 May;43(3):347-51.

15 Huang L, Jiang T, Liu C. Fetal loss after amniocentesis: analysis of a single center's 7,957 cases in China. Clin Exp Obstet Gynecol. 2015;42(2):184-7.
16 Wilson RD, Gagnon A, Audibert F, Campagnolo C, Carroll J; GENETICS COMMITTEE. Prenatal diagnosis procedures and techniques to obtain a diagnostic fetal specimen or tissue: maternal and fetal risks and benefits. J Obstet Gynaecol Can. 2015 Jul;37(7): 656-68.

17 Akolekar R, Beta J, Picciarelli G, Ogilvie C, D'Antonio F. Procedure-related risk of miscarriage following amniocentesis and chorionic villus sampling: a systematic review and meta-analysis. Ultrasound Obstet Gynecol. 2015 Jan;45(1):16-26.

18 Alfirevic Z, Navaratnam K, Mujezinovic F Amniocentesis and chorionic villus sampling for prenatal diagnosis. Cochrane Database Syst Rev. 2017 Sep;9:CD003252.

19 Geffen KT, Ben-Zvi O, Weitzner O, Peleg A, Biron-Shental T, Sukenik-Halevy R. The yield and complications of amniocentesis performed after 24 weeks of gestation. Arch Gynecol Obstet. 2017 Jul;296(1):69-75.

20 Tabor A, Philip J, Madsen M, Bang J, Obel EB, Nørgaard-Pedersen B. Randomised controlled trial of genetic amniocentesis in 4606 low-risk women. Lancet. 1986 Jun;1(8493): 1287-93.

21 Muller F, Thibaud D, Poloce F, Gelineau MC, Bernard M, Brochet C, et al. Risk of amniocentesis in women screened positive for Down syndrome with second trimester maternal serum markers. Prenat Diagn. 2002 Nov;22(11):1036-9. 
22 Kunochova I, Papcun P, Krizko M Jr, Gabor $\mathrm{M}$, Alfoldi M, Ferianec V. The value of cordocentesis in current management of intrauterine patient. Bratisl Lek Listy. 2019;120(8): 563-5.

23 Bigelow CA, Cinelli CM, Little SE, Benson CB, Frates MC, Wilkins-Haug LE. Percutaneous umbilical blood sampling: current trends and outcomes. Eur J Obstet Gynecol Reprod Biol. 2016 May;200:98-101.

24 Sasahara J, Ishii K, Fujikawa E, Mitsuda N. Current status of percutaneous umbilical cord blood sampling in Japan. J Obstet Gynaecol Res. 2019 Sep;45(9):1821-7.

25 Tongsong T, Wanapirak C, Piyamongkol W, Sirirchotiyakul S, Tongprasert F, Srisupundit $\mathrm{K}$, et al. Second-trimester cordocentesis and the risk of small for gestational age and preterm birth. Obstet Gynecol. 2014 Nov;124(5): 919-25.

26 Voekt CA, Rinderknecht T, Hirsch $\mathrm{HH}$ Blaich A, Hösli IM. Ultrasound indications for maternal STORCH testing in pregnancy. Swiss Med Wkly. 2017 Nov;147:w14534.

27 Gervasi MT, Romero R, Bracalente G, Chaiworapongsa T, Erez O, Dong Z, et al. Viral invasion of the amniotic cavity (VIAC) in the midtrimester of pregnancy. J Matern Fetal Neonatal Med. 2012 Oct;25(10):200213.

28 Crino JP, Driggers RW. Ultrasound Findings Associated With Antepartum Viral Infection. Clin Obstet Gynecol. 2018 Mar;61(1):106-21.

29 Neuberger I, Garcia J, Meyers ML, Feygin T, Bulas DI, Mirsky DM. Imaging of congenital central nervous system infections. Pediatr Radiol. 2018 Apr;48(4):513-23.

30 American College of Obstetricians and Gynecologists. Practice bulletin no. 151: Cytomegalovirus, parvovirus B19, varicella zoster, and toxoplasmosis in pregnancy. Obstet Gynecol. 2015 Jun;125(6):1510-25.

31 Oliveira GM, Pascoal-Xavier MA, Moreira DR, Guimarães VS, Aguiar RA, Miranda DM, et al. Detection of cytomegalovirus, herpes virus simplex, and parvovirus B19 in spontaneous abortion placentas. J Matern Fetal Neonatal Med. 2019 Mar;32(5):768-75.

32 Gao YL, Gao Z, He M, Liao P. Infection status of human parvovirus B19, cytomegalovirus and herpes simplex Virus-1/2 in women with first-trimester spontaneous abortions in Chongqing, China. Virol J. 2018 Apr;15(1): 74.

33 Cheshik SG, Kisteneva LB. Human cytomegalovirus infection and spontaneous abortion in pregnant women of I and II trimester. Vopr Virusol. 2016;61(2):74-8.

34 Zhou Y, Bian G, Zhou Q, Gao Z, Liao P, Liu $\mathrm{Y}$, et al. Detection of cytomegalovirus, human parvovirus B19, and herpes simplex virus-1/2 in women with first-trimester spontaneous abortions. J Med Virol. 2015 Oct;87(10): 1749-53.

35 Grammatikopoulou I, Lambropoulou M, Chatzaki E, Deftereou TE, Lambropoulou V, Simopoulou M, et al. Molecular diagnosis of
CMV infection in fetal aborted tissues in the region of Thrace. Clin Exp Obstet Gynecol. 2012;39(1):96-102.

36 Sifakis S, Ergazaki M, Sourvinos G, Koffa M, Koumantakis E, Spandidos DA. Evaluation of Parvo B19, CMV and HPV viruses in human aborted material using the polymerase chain reaction technique. Eur J Obstet Gynecol Reprod Biol. 1998 Feb;76(2):169-73.

37 Rawlinson WD, Boppana SB, Fowler KB, Kimberlin DW, Lazzarotto T, Alain S, et al. Congenital cytomegalovirus infection in pregnancy and the neonate: consensus recommendations for prevention, diagnosis, and therapy. Lancet Infect Dis. 2017 Jun;17(6): e177-88.

38 Hughes BL, Gyamfi-Bannerman C; Society for Maternal-Fetal Medicine (SMFM). Diagnosis and antenatal management of congenital cytomegalovirus infection. Am J Obstet Gynecol. 2016 Jun;214(6):B5-11.

39 Uchida A, Tanimura K, Morizane M, Fujioka $\mathrm{K}$, Morioka I, Oohashi M, et al. Clinical factors associated with congenital cytomegalovirus infection: A cohort study of pregnant women and newborns. Clin Infect Dis. 2019 Dec;pii:ciz1156.

40 Hadar E, Yogev Y, Melamed N, Chen R, Amir J, Pardo J. Periconceptional cytomegalovirus infection: pregnancy outcome and rate of vertical transmission. Prenat Diagn. 2010 Dec; 30(12-13):1213-6.

41 Griffiths PD, Baboonian C. A prospective study of primary cytomegalovirus infection during pregnancy: final report. Br J Obstet Gynaecol. 1984 Apr;91(4):307-15.

42 Bascietto F, Liberati M, Murgano D, Buca D, Iacovelli A, Flacco ME, et al. Outcome of fetuses with congenital parvovirus B19 infection: systematic review and meta-analysis. Ultrasound Obstet Gynecol. 2018 Nov;52(5): 569-76.

43 Nayeri T, Sarvi S, Moosazadeh M, Amouei A, Hosseininejad Z, Daryani A. The global seroprevalence of anti-Toxoplasma gondii antibodies in women who had spontaneous abortion: A systematic review and meta-analysis. PLoSNeglTropDis.2020Mar;14(3):e0008103.

44 Sauerbrei A, Wutzler P. Varicella-zoster virus infections during pregnancy: epidemiology, clinical symptoms, diagnosis, prevention and therapy. Curr Pediatr Rev. 2005;1(3):205-15.

45 Enders G, Miller E, Cradock-Watson J, Bolley I, Ridehalgh M. Consequences of varicella and herpes zoster in pregnancy: prospective study of 1739 cases. Lancet. 1994 Jun; 343(8912):1548-51.

46 Daum H, Ben David A, Nadjari M, Zenvirt S, Helman S, Yanai N, et al. Role of late amniocentesis in the era of modern genomic technologies. Ultrasound Obstet Gynecol. 2019 May;53(5):676-85.

47 Gabbay-Benziv R, Yogev Y, Melamed N, BenHaroush A, Meizner I, Pardo J. Pregnancy outcome after third trimester amniocentesis: a single center experience. J Matern Fetal Neonatal Med. 2012 Jun;25(6):666-8.
48 Weisz B, Book M, Lipitz S, Katorza E, Achiron $\mathrm{R}$, Grossman Z, et al. Fetal outcome and amniocentesis results in pregnancies complicated by varicella infection. J Obstet Gynaecol Can. 2011 Jul;33(7):720-4.

49 Mouly F, Mirlesse V, Méritet JF, Rozenberg F, Poissonier MH, Lebon P, et al. Prenatal diagnosis of fetal varicella-zoster virus infection with polymerase chain reaction of amniotic fluid in 107 cases. Am J Obstet Gynecol. 1997 Oct;177(4):894-8.

50 Lipitz S, Elkan Miller T, Yinon Y, Weissbach T, De-Castro H, Hoffman C, et al. Revisiting the short and long outcome after fetal firsttrimester primary cytomegalovirus infection in relation to prenatal imaging findings. Ultrasound Obstet Gynecol. doi: 10.1002/ uog.21946 [Epub ahead of print].

51 Hawkins-Villarreal A, Moreno-Espinosa AL Eixarch E, Marcos MA, Martinez-Portilla RJ, Salazar L, et al. Blood parameters in fetuses infected with cytomegalovirus according to the severity of brain damage and trimester of pregnancy at cordocentesis. J Clin Virol. 2019 Oct;119:37-43.

52 Simonazzi G, Cervi F, Zavatta A, Pellizzoni L, Guerra B, Mastroroberto M, et al. Congenital Cytomegalovirus Infection: Prognostic Value of Maternal DNAemia at Amniocentesis. Clin Infect Dis. 2017 Jan;64(2):207-10

53 Enders M, Daiminger A, Exler S, Enders G, Enders G, Bold R. Amniocentesis for prenatal diagnosis of cytomegalovirus infection: challenging the 21 weeks' threshold. Prenat Diagn. 2017 Sep;37(9):940-2.

54 Revello MG, Furione M, Zavattoni M, Tassis B, Nicolini U, Fabbri E, et al. Human cytomegalovirus (HCMV) DNAemia in the mother at amniocentesis as a risk factor for iatrogenic HCMV infection of the fetus. J Infect Dis. 2008 Feb;197(4):593-6.

55 Donadono V, Saccone G, Maruotti GM, Berghella V, Migliorini S, Esposito G, et al. Incidence of toxoplasmosis in pregnancy in Campania: A population-based study on screening, treatment, and outcome. Eur J Obstet Gynecol Reprod Biol. 2019 Sep;240:316-21.

56 Findal G, Helbig A, Haugen G, Jenum PA, Stray-Pedersen B. Management of suspected primary Toxoplasma gondii infection in pregnant women in Norway: twenty years of experience of amniocentesis in a low-prevalence population. BMC Pregnancy Childbirth. 2017 Apr;17(1):127-36.

57 Leruez-Ville M, Stirnemann J, Sellier Y, Guilleminot T, Dejean A, Magny JF, et al. Feasibility of predicting the outcome of fetal infection with cytomegalovirus at the time of prenatal diagnosis. Am J Obstet Gynecol. 2016 Sep; 215(3):342.e1-9.

58 Faure-Bardon V, Millischer AE, Deloison B, Sonigo P, Grevent D, Salomon L, et al. Refining the prognosis of fetuses infected with $\mathrm{Cy}$ tomegalovirus in the first trimester of pregnancy by serial prenatal assessment: a singlecentre retrospective study. BJOG. $2020 \mathrm{Feb}$ 127(3):355-62.
Perinatal Infection and Intrauterine Testing
Fetal Diagn Ther 2020;47:653-664 DOI: $10.1159 / 000508042$ 
59 Blázquez-Gamero D, Galindo Izquierdo A, Del Rosal T, Baquero-Artigao F, Izquierdo Méndez N, Soriano-Ramos M, et al. Prevention and treatment of fetal cytomegalovirus infection with cytomegalovirus hyperimmune globulin: a multicenter study in $\mathrm{Ma}$ drid. J Matern Fetal Neonatal Med. 2019 Feb; 32(4):617-25

60 Kagan KO, Hamprecht K. Cytomegalovirus infection in pregnancy. Arch Gynecol Obstet. 2017 Jul;296(1):15-26.

61 Leruez-Ville M, Ville Y. Fetal cytomegalovirus infection. Best Pract Res Clin Obstet Gynaecol. 2017 Jan;38:97-107.

62 Naing ZW, Scott GM, Shand A, Hamilton ST, van Zuylen WJ, Basha J, et al. Congenital cytomegalovirus infection in pregnancy: a review of prevalence, clinical features, diagnosis and prevention. Aust N Z J Obstet Gynaecol. 2016 Feb;56(1):9-18.

63 Nigro G. Hyperimmune globulin in pregnancy for the prevention of congenital cytomegalovirus disease. Expert Rev Anti Infect Ther. 2017 Nov; 15(11):977-86.

64 Khalil A, Heath P, Jones C, Soe A, Ville YG. Congenital Cytomegalovirus Infection: Update on Treatment. Scientific Impact Paper No. 56. BJOG. 2018;125:e1-11.

65 Crane J, Mundle W, Boucoiran I, Gagnon R, Bujold E, Basso M, et al.; Maternal Fetal Medicine Committee. Parvovirus B19 infection in pregnancy. J Obstet Gynaecol Can. 2014 Dec; 36(12):1107-16.

66 March of Dimes Fifth Disease and Pregnancy. Available from: www.marchofdimes.org/ complications/fifth-disease-and-pregnancy. aspx [accessed January 16, 2020].

67 Paquet C, Yudin MH. No. 285 - Toxoplasmosis in Pregnancy: Prevention, Screening, and Treatment. J Obstet Gynaecol Can. 2018 Aug; 40(8):e687-93.

68 Wallon M, Peyron F. Congenital Toxoplasmosis: A Plea for a Neglected Disease. Pathogens. 2018 Feb;7(1):25-34.
69 Montoya JG. Systematic screening and treatment of toxoplasmosis during pregnancy: is the glass half full or half empty? Am J Obstet Gynecol. 2018 Oct;219(4):315-9.

70 Shrim A, Koren GK, Yudin MH, Farine D. No. 274 - Management of Varicella Infection (Chickenpox) in Pregnancy. J Obstet Gynaecol Can. 2018 Aug;40(8):e652-7.

71 Chickenpox in Pregnancy. Green-top Guideline No. 13 January 2015 Guidelines Committee of the RCOG; Royal College of Obstetricians and Gynaecologists/NICE accredited.

72 Ahn KH, Park YJ, Hong SC, Lee EH, Lee JS, Oh $\mathrm{MJ}$, et al. Congenital varicella syndrome: A systematic review. J Obstet Gynaecol. 2016 Jul;36(5):563-6.

73 Wilson E, Goss MA, Marin M, Shields KE, Seward JF, Rasmussen SA, et al. Varicella vaccine exposure during pregnancy: data from 10 Years of the pregnancy registry. J Infect Dis. 2008 Mar;197(Suppl 2):S178-84.

74 Wou K, Chung WK, Wapner RJ. Laboratory considerations for prenatal genetic testing. Semin Perinatol. 2018 Aug;42(5):307-13.

75 Wojcik MH, Reimers R, Poorvu T, Agrawal PB. Genetic diagnosis in the fetus. J Perinatol. doi: 10.1038/s41372-020-0627-z [Epub ahead of print].

76 Shi Y, Ma J, Xue Y, Wang J, Yu B, Wang T. The assessment of combined karyotype analysis and chromosomal microarray in pregnant women of advanced maternal age: a multicenter study. Ann Transl Med. 2019 Jul; 7(14):318

77 Petrovski S, Aggarwal V, Giordano JL, Stosic $\mathrm{M}$, Wou K, Bier L, et al. Whole-exome sequencing in the evaluation of fetal structural anomalies: a prospective cohort study. Lancet. 2019 Feb;393(10173):758-67.

78 Sadlecki P, Grabiec M, Walentowicz P Walentowicz-Sadlecka M. Why do patients decline amniocentesis? Analysis of factors influencing the decision to refuse invasive prenatal testing. BMC Pregnancy Childbirth. 2018 May;18(1):174-81.
79 Malan V, Bussières L, Winer N, Jais JP, Baptiste A, Le Lorc'h M, et al.; SAFE 21 Study Group. Effect of Cell-Free DNA Screening vs Direct Invasive Diagnosis on Miscarriage Rates in Women With Pregnancies at High Risk of Trisomy 21: A Randomized Clinical Trial. JAMA. 2018 Aug;320(6):557-65.

80 Tabor A, Vestergaard CH, Lidegaard Ø. Fetal loss rate after chorionic villus sampling and amniocentesis: an 11-year national registry study. Ultrasound Obstet Gynecol. 2009 Jul; 34(1):19-24.

81 Arora N, Sadovsky Y, Dermody TS, Coyne CB. Microbial Vertical Transmission during Human Pregnancy. Cell Host Microbe. 2017 May;21(5):561-7.

82 Mandelbrot L. Fetal varicella - diagnosis, management, and outcome. Prenat Diagn. 2012 Jun;32(6):511-8.

83 Giorlandino C, Gambuzza G, D’Alessio P, Santoro ML, Gentili P, Vizzone A. Blood contamination of amniotic fluid after amniocentesis in relation to placental location. Prenat Diagn. 1996 Feb;16(2):180-2.

84 Siegel AM, Clinton CM, Post AL, Truong T, Pieper CF, Hughes BL. Assessing patient perceptions of cytomegalovirus infection in pregnancy. J Med Virol. doi: 10.1002/ jmv.25714 [Epub ahead of print].

85 Leruez-Ville M, Foulon I, Pass R, Ville Y. Cytomegalovirus infection during pregnancy: state of the science. Am J Obstet Gynecol. doi: 10.1016/j.ajog.2020.02.018 [Epub ahead of print].

86 Gabbay-Benziv R, Yogev Y, Peled Y, Amir J, Pardo J. Congenital cytomegalovirus infection following antenatal negative diagnostic amniotic fluid analysis - a single center experience. J Matern Fetal Neonatal Med. 2012 Sep;25(9):1787-90. 